\title{
Service Learning: A Powerful Approach to the Introduction of Engineering Design for Freshmen
}

\author{
Jean Brousseau, Ph.D., ing. \\ Engineering professor \\ Abderrazak ElOuafi, Ph.D. \\ Engineering professor \\ Suzie Loubert, ing. \\ Research assistant \\ Jean_Brousseau@uqar.qc.ca \\ Abderrazak_ElOuafi@uqar.qc.ca \\ Suzie_Loubert@uqar.qc.ca \\ Université du Québec à Rimouski \\ Département de mathématiques, d'informatique et de génie
}

\begin{abstract}
Service learning is a very interesting pedagogical approach for engineering education. It can be used in most engineering courses, but it fits very well in a project-based design course. Through service learning, the students work with a real customer, apply all the steps of the design cycle, deliver a functional prototype, manage a real project, understand the multi-faceted responsibilities of an engineer and develop team work and communication skills.

The approach was introduced in an existing, first year, first semester, design course. The experience shows that projects can be found in the community without too much effort, students perform very well and can deliver functional and useful prototypes in four months. Before introducing the service learning approach, the course was already well evaluated and is even more appreciated now. The conclusion is that service learning is a perfect approach for a course that was designed to introduce students to real-world problems in engineering at the start of their engineering education.
\end{abstract}

\section{Introduction}

Service learning is an educational approach that integrates classroom learning into community service. Research has shown that this association can improve learning while providing valuable services to the community. When applied to the field of engineering, service learning offers an opportunity for students to learn and practise engineering design while engaging them in projects addressing real human and community needs. Student Engineers involved in community based projects also have the possibility of demonstrating their understanding of professional and ethical responsibilities. When service learning is used in project design courses, students learn by putting theory into practice, face real customer needs, work on projects that have real community impacts and are placed in the context of an actual professional engineer. This is a very attractive approach for design education.

The objective of this paper is to emphasize the viability of service learning as an educational method in building design skills that help meet engineering education challenges and CEAB criteria [1]. It introduces the concept of service learning, its main features, and presents some of the resources available for faculties wanting to integrate service learning into their engineering courses. This paper also shows that the approach can be introduced in first year design courses even though freshmen do not have a lot of technical knowledge. To prove the point, the paper illustrates how the service learning strategy has been incorporated into an introductory design course and how well the students performed in delivering functional prototypes to non-profit organizations. Finally it provides an assessment of the impact on student motivation, commitment and attainment of their learning objectives.

\section{What is service learning?}

According to Wikipedia1, «Service-learning is a method of teaching, learning and reflecting that combines academic classroom curriculum with meaningful service throughout the community. As a teaching methodology, it falls under the category of experiential education. More specifically, it integrates meaningful community service with instruction and reflection to enrich the learning experience, teach civic responsibility, encourage lifelong civic engagement, and strengthen communities for the common good».

\footnotetext{
${ }^{1}$ http://en.wikipedia.org/wiki/Service_learning
} 
The opportunities for service in the community are numerous and cover a wide variety of needs. Nonprofit organizations have many more needs than means to achieve them. With their skills and knowledge, engineering students can perform very valuable services to the community. The key elements of the approach are: a valuable and useful service to community, a real connection with the academic material, a win-win relationship and partnership between students, faculty and the community and the analysis and reflection that have to be done during and at the end of the learning cycle.

Service learning is relatively common throughout university programs. According to Campus Compact2 and across all its member institutions, 12480 service-learning courses were offered during the 2004-05 academic year. In the United States, the approach is well established and documented in many engineering faculties. For example, the group "Engineering Projects in Community Service"3 (EPICS) is a consortium of universities across the United States committed to, and successfully practising, service learning. The EPICS project was founded in 1995 at the Purdue University. In Canadian engineering programs, service learning is certainly used, but is not as well established and widespread as in the United States. There are many very valuable resources (books [2-3], papers, electronic journal [4] and WEB sites [5-6]) available for anyone who wants to use the approach.

Service learning can be integrated into most engineering courses, but it is a perfect approach for learning and practising design. It gives real-world context for the development of design competency. In a project-based design course, service learning gives the opportunity to work with a real customer, meet desired needs, solve real problems using modern tools, apply all the steps of the design cycle, deliver a functional prototype, manage a real project, understand professional and ethical responsibilities of the engineer and develop team work and communication skills. Service learning challenges the students. In fact, the community partners often lack the budget and the capability to get the work done and, for that reason, demand quality because they rely on the results. In addition and in the wider context of engineering education, service learning is very attractive because it provides a means to present a different image of engineering.

\footnotetext{
${ }^{2}$ Campus Compact: American coalition of nearly 1100 college and university presidents who are committed to fulfilling the civic purposes of higher education. WEB site: www.compact.org

${ }^{3}$ WEB site of EPICS: epicsnational.ecn.purdue.edu
}

In a very larger context, service learning helps students to become better engineers. It offers many opportunities to address both the qualitative and quantitative criteria of $\mathrm{CEAB}$ [1]. If service learning can help meet educational challenges that are often difficult to deal with in traditional courses, it is also suitable to lead students to master traditional elements of the engineering curriculum. For instance, service learning when integrated into a course can bring the students to apply knowledge, solve engineering problems, design for specific needs, conduct experiments, analyze and interpret data, work in a team, understand the professional and ethical responsibilities of an engineer, learn to communicate, understand the impact of the technology, become aware of contemporary issues and use techniques, skills, and modern engineering tools. When students are taking a course using service learning pedagogy, they are involved in a situation that helps them acquire the fundamental values of the profession: competency, ethical conduct, responsibility and social commitment. The students have to be competent when applying scientific principles and knowledge for mastering the mandate to the customer satisfaction. They must also be responsible and complete the mandate. A product rarely works as expected at the first trial. Any product almost always needs to be modified and improved. Moreover, students working with a community partner should demonstrate conduct beyond reproach and their top priority must be the interest of society and the client, as in real life. Finally, the students involved in a project for a community partner discover the meaning of social commitment.

\section{Implementing service learning into an introductory design course}

Because design is a skill or behavior that is acquired with experience [7] but also based on techniques and tools [8], it is advisable to offer students the opportunity to gain various experiences throughout the full extent of the student's curriculum. The sequence of project-based design courses, which are an important part (the sixth) of UQAR's engineering programs, begins in the first semester with a course entitled «Engineering, Design, and Communication». When the program team decided to introduce a first semester project oriented course, there were concerns that the technical knowledge of new students might be insufficient to undertake such a course. Experience now shows that these courses can be successfully and favourably integrated into engineering programs as early as the first year. When service learning attracted our attention for the 
freshman project-based design course, there were concerns that the new students might not be ready to undertake a real project and deliver a prototype by the end of a four month semester. In addition, there were doubts about the possibility of identifying what the freshman students could do in the corresponding community projects. We knew that the projects had to take into account that the students were just undertaking their engineering program, without, for most of them, any experience in design. Experience now shows that our first year students are able to reach the target beyond the expectations. The quality of the products they design, build and deliver to the community partners clearly shows that the new students are able to undertake a course in design and a project with a nonprofit organization. There is no doubt, service learning can be successfully integrated into engineering programs as early as the first year.

\section{Description of the "Engineering, Design and Communication" course}

Service learning was introduced in the «Engineering, Design, and Communication» course in autumn 2005. Before, the projects proposed to the students were more academic and not related to the needs of a real customer. The students appreciated the course and nothing indicated that a change was necessary. Even if the course was going fine, we were convinced that the students could be even more motivated.

The "Engineering, Design and Communication" course is divided into three closely related sections. The engineering section examines the various sides of the profession: the fields of specialization, the duties and responsibilities of the engineer, and the role of the association of professional engineers. The second section reviews the methodology used to develop technical products based on Ulrich's [9] procedure. Through teamwork and various projects, students must carry out the steps involved in developing a new product from its conception to the manufacture of a prototype. The third section presents the fundamentals of interpersonal communication skills, efficient teamwork, technical writing, oral presentations and the essentials of graphical communication. In the third part, they also learn how to use the basics of CAD software. The six weekly hours are divided between lectures and teamwork periods, but the central part of the course is the hands-on design experience.

Essentially, students must carry out a short and long project. The short project is a design competition between teams that takes place at the beginning of the year. The objective is to have students fully experience a design project while intuitively following the methodology used to develop a product. We normally give approximately two weeks to the short project. Technical concepts, related to the challenging problems, are discussed during project presentations and prototype testing. In the autumn 2005 semester, we asked students to design and build a pair of shoes for walking on water. In the autumn 2006, we asked students to design and build, from a given box of material, a pick-puck robot. On a 4' x 8' playground, two robots fight for a hockey puck. A game lasts 1 minute.

The long project has a greater scope. Students work in a team of three to five and devote approximately 14 weeks to the project, thus enabling them to go through all the steps involved in developing a product. The level of difficulty of the project takes into account that the student complement is composed of students coming from the math-science pre-university programs and of young mechanical and electrical professional technicians. So, the students have a large range of skills that can be exploited in the projects. The evaluation of the projects is based on progress reports, a final report, two oral presentations, the prototype and the project's logbook.

Table 1 presents, for the version of the course using the service learning approach, a summary of the course outline: rough schedule, teamwork assignments, subjects covered in the lectures, the deliverables and others activities. Even if the course workload is quit heavy, the students do not complain. They are very motivated and enthusiastic. We believe it is due to the course context.

\section{Finding partners, selecting projects and grouping the students around the projects}

Even if it is possible to work with nonprofit organizations located far from the university, it is more practical to work with the local community. The customers are more accessible, long term partnership are easier to maintain, and students can be directly concerned with the mission of the organization. In every local environment, there are many nonprofit organizations such as community service agencies, schools, museums, and local government offices. They have many needs that rely upon technology. Most of the organizations visited had needs and technological projects not undertaken because they often possess neither the expertise nor the budget to fulfill their needs. The help from the engineering students is always welcome. Engineering students, even those at the beginning of their engineering program, often possess the required technical skills to satisfy the 


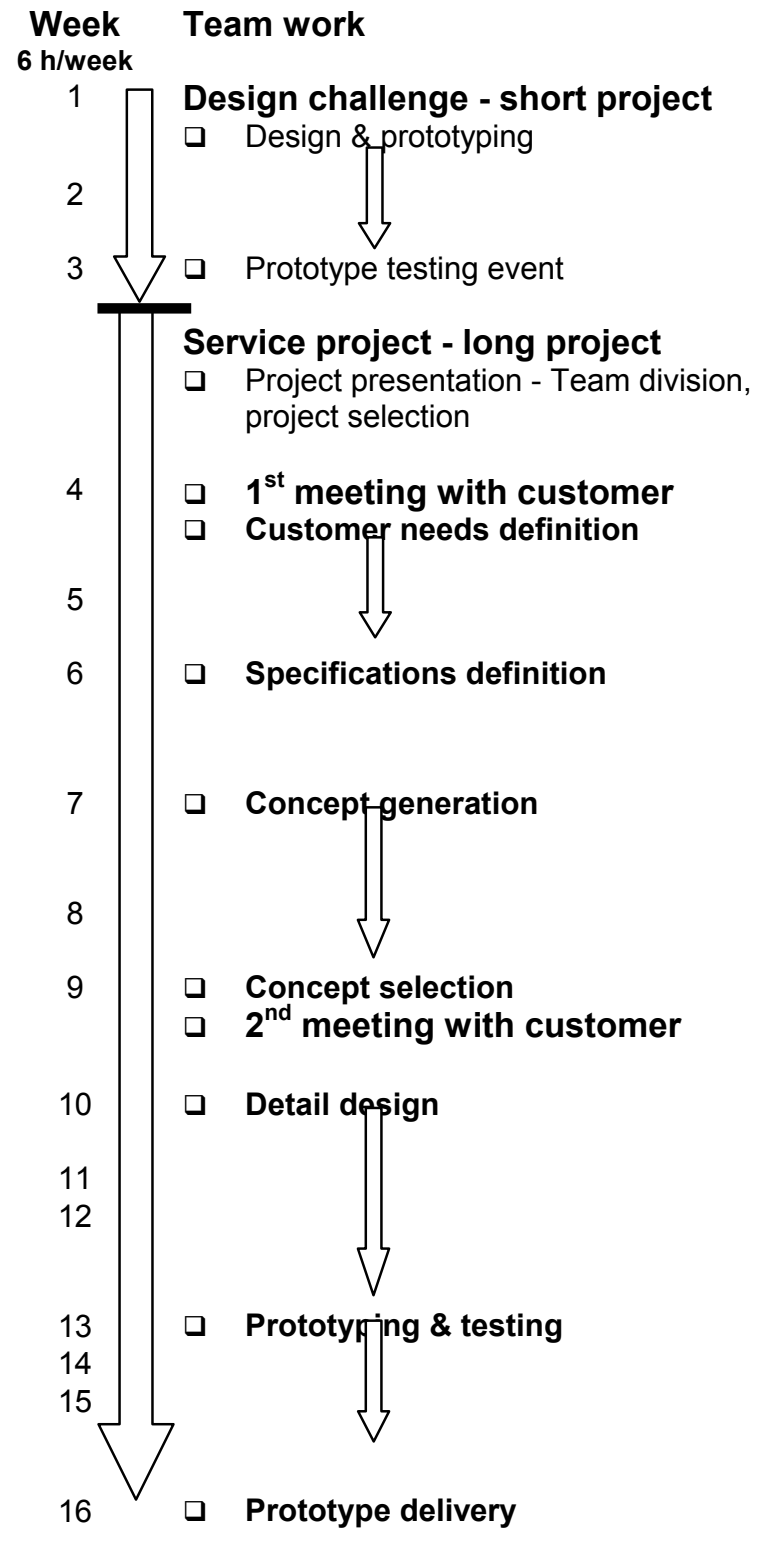

\section{Lectures \\ Deliverables}

․ Engineering: fields \& responsibilities

- Design methodology -overview

- Psychological types \& MBTI

a Team work - efficient team

口 Project planning

ㅁ Efficient Meeting

Team work - conflict management

Identifying needs

a Technical writing - part 1

Technical writing - part 2

- Technical specifications

ㅁ Concept generation

- Professional corporation of engineers

․ Concept selection

- Technical drawing - part 1

ㅁ Product architecture

Detail design

Technical drawing part 2

口 Prototyping

a Technical drawing - part 3

․ Technical drawing - part 4

\section{Other activities}

․ Prototype of short project and cost report

a Team contract

a Team internal government

口 Project mission

- Report of the customer meeting

口

Progress report 1

- Oral presentation of selected concept

口

SolidWorks training 1

ㅁ Progress report 2

SolidWorks training 2

SolidWorks training 3 SolidWorks training 4

SolidWorks training 5
ㅁ Progress report 3

- Practical exam on solidworks

a Final report, prototype and oral presentation

Figure 1. Flow chart of the course 
customer's needs. It is surprising how resourceful our students are when they are motivated. When trying to define projects for our freshman students, we consider the nature, the scope and the cost of the project. The nature of the project must correspond to the field of study of our students and be feasible in four months, prototype included. The best way to find projects is to meet and discuss with the people working in the organization. Often, the staff of an organization is not able to identify what a group of engineering students can do. Identifying a project is a question of teamwork between people from the organization and from the university. Because the engineering department financially supports the service projects, we have tried to keep the direct costs of each project under the $400 \$$ limit. In some cases, the partners have accepted absorbing the surplus.

We have not yet explored the possibility of letting the students identify the projects by themselves. It could be a valuable experience, but we believe it is too time consuming. In the context of a one semester course and project, we have preferred to find the projects, define the board lines with the customer and propose them to the group of students.

There are many ways to form teams and distribute projects. We have chosen to let the students gather around the projects by interest. We want the students to be motivated as much as possible by their project. Many of our students have technical skills and personal resources that can be favourably exploited. The students are often more motivated when they feel they can be useful. The operation of grouping the students around the projects starts by the presentation of the projects. Then, each student identifies the three first choices. The professor and his assistant try to reconcile the students' demands. Discussions with some students are occasionally necessary to complete the operation.

\section{Project examples}

This section presents two examples of projects completed in the course. For each example, the nonprofit organization is identified and a very brief description of the product delivered to the customer is given. The idea is to show the nature and the scope of the projects that our students were able to complete in the context of a first semester project-based design course using service-the learning approach.

\section{Project 1}

Customer: Football team of Rimouski College (Cégep de Rimouski)

Need: Try simulator

During training, the coach wanted to propose different play situations on an electronic display. The play situations must be randomly chosen and the try and the distance to cover must be displayed. An old display working small light bulbs was available and supplied to the team.

\section{Product designed by the students}

The student team proposed a wireless device that commands the display. Each time the coach pushes the button of the remote control, the display shows a new try. The display is controlled by microcontrollers MSP430 from Texas Instruments.

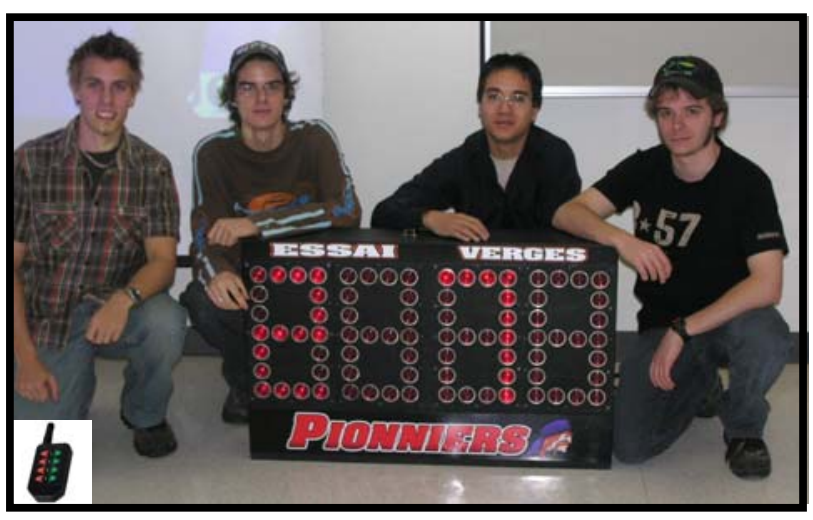

Figure 1. Try simulator for a football team

\section{Project 2}

Customer: Paraloeil

Paraloeil is a nonprofit organization working as a media arts center. It promotes the Canadian cinematographic and videographic production. It also supports local productions and rents equipment.

Need: cinematographic cart

Paraloeil rents audiovisual equipment to local amateur and semi-professional producers. The organization had neither shooting cart nor the budget to acquire one. Paraloeil proposed the project of building a cart to the engineering students.

\section{Product designed by the students}

The students proposed a cart that can be put in the trunk of a medium size car. The cart also has an adjustable turning chair and a camera support. 


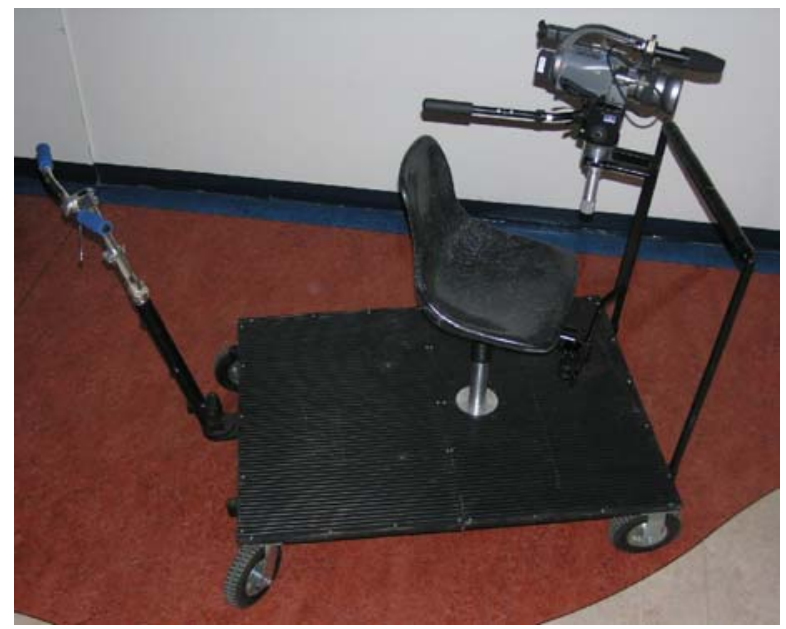

Figure 2: Cinematographic cart for Paraloeil

\section{Course assessment}

In order to have an idea of the students' satisfaction with service learning, we looked at the results of the course evaluation for two groups. The Group A (47 students) took the traditional course without the service learning approach. On the other hand, the Group B (42 students) took the course and delivered service in the community. Both groups had the same professor. From the course assessment questionnaire, five questions attracted our attention (see table 2). Each question was evaluated on a four level Likert type scale (strongly agree, agree, disagree, strongly disagree). Table 2 presents the responses expressed in percentages for the five questions and the two groups of students. It is clear from the results that both groups have evaluated the course well. According to the students' point of view, the following can be concluded:

口 the workload has slightly increased since the introduction of service learning;

a the course is more stimulating with the service learning approach;

u the pedagogical approach is more appreciated;

口 the contents are more relevant;

口 the course gives about the same possibilities to integrate knowledge, abilities and attitudes.

The conclusion is that service learning is a perfect approach for a course that was designed to introduce students to real-world problems in engineering at the start of their engineering education. The approach certainly requires more supervision and continuous support from the professor, but the experience shows that it is worth the effort.

Table 2: Students' satisfaction assessment

\begin{tabular}{|c|c|c|c|c|c|c|c|c|}
\hline & \multicolumn{2}{|c|}{$\begin{array}{l}\text { Strongly } \\
\text { agree }\end{array}$} & \multicolumn{2}{|c|}{ Agree } & \multicolumn{2}{|c|}{ Disagree } & \multicolumn{2}{|c|}{$\begin{array}{l}\text { Strongly } \\
\text { disagree }\end{array}$} \\
\hline & GA & GB & GA & GB & GA & GB & GA & GB \\
\hline Q12 & 50 & 52 & 40 & 31 & 8 & 14 & 2 & 2 \\
\hline Q16 & 63 & 71 & 33 & 21 & 4 & 5 & 0 & 2 \\
\hline Q17 & 56 & 81 & 44 & 19 & 0 & 0 & 0 & 0 \\
\hline Q26 & 66 & 85 & 32 & 15 & 2 & 0 & 0 & 0 \\
\hline Q27 & 77 & 78 & 23 & 17 & 0 & 5 & 0 & 0 \\
\hline \multicolumn{9}{|c|}{ Q12: The course workload is usual } \\
\hline \multicolumn{9}{|c|}{ Q16: The hands-on work stimulates my interest } \\
\hline \multicolumn{9}{|c|}{$\begin{array}{l}\text { Q17: On the whole, the pedagogical approach } \\
\text { helps to reach the goals of the course }\end{array}$} \\
\hline \multicolumn{9}{|c|}{$\begin{array}{l}\text { Q26: The contents of the course give the } \\
\text { possibility to progress in the field of study }\end{array}$} \\
\hline \multicolumn{9}{|c|}{$\begin{array}{c}\text { Q27: The course gives the possibility to integrate } \\
\text { knowledge, abilities and attitudes }\end{array}$} \\
\hline
\end{tabular}

\section{References}

[1] CEAB: Canadian Engineering Accreditation Board, Accreditation criteria and procedures, 2006.

[2] Lima Marybeth and William Oakes, "Service Learning engineering community", great lakes press, 2006.

[3] Oakes, William, "Service learning in engineering, an resource guide book", Campus Compact, 2004 (available at http:/www.compact.org/publications/detail/servicelearning_in_engineering)

[4] International Journal for Service Learning in Engineering, Penn State University, http://www.engr.psu.edu/IJSLE/home.htm

[5] National Service-Learning Clearinghouse, The national site for service learning information.

http://www.servicelearning.org/resources/quick_guides/eng ed/

[6] Canadian Association for Community Service-Learning, www.communityservicelearning.ca/en/

[7] Koen, Billy V., "Toward a Strategy for Teaching Engineering Design", Journal of Engineering Education, July 1994.

[8] Dally J.W., Zhang G.M., "A Freshman Engineering Design Course", Journal of Engineering Education, April 1993.

[9] Ulrich, K.T., et Eppinger, S.D., "Product Design and Development", McGraw-Hill, 1995 